\title{
Exendin-4 induction of cyclin D1 expression in INS-1 $\beta$-cells: involvement of cAMP-responsive element
}

\author{
M-J Kim ${ }^{1 *}$, J-H Kang ${ }^{1 *}$, Y G Park ${ }^{2}$, G R Ryu ${ }^{1}$, S H Ko ${ }^{3}$, \\ I-K Jeong ${ }^{4}$, K-H Koh ${ }^{5}$, D-J Rhie ${ }^{1}$, S H Yoon ${ }^{1}$, S J Hahn ${ }^{1}$, \\ M-S Kim ${ }^{1}$ and Y-H Jo ${ }^{1}$ \\ Departments of ${ }^{1}$ Physiology and ${ }^{3}$ Internal Medicine, College of Medicine, The Catholic University of Korea, Seoul 137-701, Korea \\ ${ }^{2}$ Department of Biochemistry, College of Medicine, Korea University, Seoul 136-701, Korea \\ ${ }^{4}$ Department of Internal Medicine, School of Medicine, Hallym University, Seoul 150-030, Korea \\ ${ }^{5}$ Department of Food Science and Nutrition, The Catholic University of Korea, Puchon City 420-743, Korea \\ (Requests for offprints should be addressed to Y-H Jo; Email: yhjo@catholic.ac.kr) \\ *(M-J Kim and J-H Kang contributed equally to this study)
}

\begin{abstract}
Glucagon-like peptide-1 (GLP-1) and its analog exendin-4 (EX) have been considered as a growth factor implicated in pancreatic islet mass increase and $\beta$-cell proliferation. This study aimed to investigate the effect of EX on cyclin D1 expression, a key regulator of the cell cycle, in the pancreatic $\beta$-cell line INS-1. We demonstrated that EX significantly increased cyclin D1 mRNA and subsequently its protein levels. Although EX induced phosphorylation of Raf-1 and extracellular-signal-regulated kinase (ERK), both PD98059 and exogenous ERK1 had no effect on the cyclin D1 induction by EX. Instead, the cAMP-elevating agent forskolin induced cyclin D1 expression remarkably and this response was inhibited by pretreatment with $\mathrm{H}-89$, a protein kinase A (PKA) inhibitor. Promoter analyses revealed that the cAMP-responsive element (CRE) site (at position -48; 5'-TAACGTCA-3') of cyclin D1 gene was required for both basal and EX-induced activation of the cyclin D1 promoter, which
\end{abstract}

was confirmed by site-directed mutagenesis study. For EX to activate the cyclin D1 promoter effectively, CRE-binding protein (CREB) should be phosphorylated and bound to the putative CRE site, according to the results of electrophoretic mobility shift and chromatin immunoprecipitation assays. Lastly, a transfection assay employing constitutively active or dominant-negative CREB expression plasmids clearly demonstrated that CREB was largely involved in both basal and EX-induced cyclin D1 promoter activities. Taken together, EXinduced cyclin D1 expression is largely dependent on the cAMP/PKA signaling pathway, and EX increases the level of phosphorylated CREB and more potently transactivates cyclin D1 gene through binding of the CREB to the putative CRE site, implicating a potential mechanism underlying $\beta$-cell proliferation by EX.

Journal of Endocrinology (2006) 188, 623-633

\section{Introduction}

Glucagon-like peptide-1 (GLP-1) has been of much interest due to its $\beta$-cell-proliferating effect and role as an incretin hormone in synergizing with glucose to enhance insulin release (Ørskov 1992, Egan et al. 2003). Although many anti-diabetic effects of GLP-1 have been evaluated under conditions in vivo and in vitro (Perfetti \& Merkel 2000, De León et al. 2003), the short duration of action due to dipeptidyl peptidase IV-mediated degradation has limited its clinical application (Perfetti \& Merkel 2000).

Exendin-4 (EX), a GLP-1 receptor agonist, is more stable under conditions in vivo because of its resistance to dipeptidyl peptidase IV-mediated degradation (Perry \& Greig 2003). EX has also been known to stimulate $\beta$-cell proliferation and islet mass increase under both in vivo and in vitro conditions (Xu et al. 1999, Tourrel et al. 2001, 2002). Due to these beneficial effects, exenatide, a synthetic EX, is now used as an adjunctive therapeutic agent for type 2 diabetes (for more information visit http://www.byetta.com).

Cyclin D1 is a major cell-cycle regulator involved in progressing cells to the proliferative stage, and the overexpression of cyclin D1 shortens the $G_{1}$ phase, thereby leading to rapid entry into the $S$ phase (Sherr 1994). Cyclin D1 gene expression is largely regulated at the transcriptional level, although posttranscriptional mechanisms are also involved (Yan et al. 1997).

Both GLP-1 and EX bind to GLP-1 receptor coupled with $G_{s}$ proteins, which stimulates adenylate cyclase, 
leading to an increase in intracellular cAMP levels and an activation of protein kinase A (PKA; Drucker et al. 1987, Leech et al. 1999). cAMP-responsive element (CRE)binding protein (CREB) is a major PKA substrate and belongs to the ATF/CREB transcription factor family that interacts with CRE site in the CAMP-responsive gene promoter (Montminy 1997). Since the proximal region of both human and rat cyclin D1 gene promoters contain a putative CRE site $\left(5^{\prime}-\right.$ TAACGTCA-3') similar to the consensus CRE site (5'-TGACGTCA-3'), it can be assumed that the effect of EX on cyclin D1 promoter activity is mediated by a conventional cAMP signaling mechanism. However, the involvements of the CRE site and of transcription factors binding to the CRE site in cyclin D1 promoter activity have not been examined in pancreatic $\beta$-cells.

This study investigated the induction of cyclin D1 expression in INS-1 $\beta$-cells by EX and the involvement of the CRE site and the transcription factor CREB in the EX-activated cyclin D1 gene promoter.

\section{Materials and Methods}

\section{Materials}

All reagents for cell culture were purchased from Gibco BRL. EX, exendin-(9-39) amide, and GLP-1-(7-36) amide were from Bachem AG (Torrance, CA, USA). Glucose-dependent insulinotropic peptide (GIP) receptor antagonist GIP-(6-30) was kindly provided from Dr C M Isales (Institute of Molecular Medicine and Genetics, Medical College of Georgia, Augusta, GA, USA). SP600125, forskolin, SB203580, PD98059, H-89, and anti-rabbit c-Fos and anti-rabbit c-Jun antibodies were from Calbiochem (La Jolla, CA, USA). Anti-mouse cyclin D1 and anti-mouse c-Raf antibodies were from BD Transduction Laboratories (Palo Alto, CA, USA). Anti-rabbit extracellular-signal-regulated kinase (ERK), anti-mouse phospho-ERK, anti-rabbit phospho-Raf, anti-rabbit phospho-CREB, anti-rabbit ATF-2, and antirabbit phospho-ATF-2 antibodies were from Cell Signaling Technology (Beverly, MA, USA). Anti-mouse CREB and anti-mouse $\beta$-tubulin antibodies, and Western Blotting Luminol Reagent, were from Santa Cruz Biotechnology (Santa Cruz, CA, USA).

\section{Isolation of pancreatic islet and culture of INS-1 cells}

Pancreatic islets were isolated from Sprague-Dawley rats (Daehan Biolink Company, Chungbuk, Korea) using collagenase digestion and Ficoll gradient separation, as described previously (Kim et al. 2003). INS-1 cells (passages 21-30) were cultured in RPMI 1640 containing $10 \mathrm{mM}$ HEPES, $5.6 \mathrm{mM}$ D-glucose, $10 \%$ fetal bovine serum, $1 \mathrm{mM}$ sodium pyruvate, $2 \mathrm{mM}$ L-glutamine,
$50 \mu \mathrm{M}$ 2-mercaptoethanol, and antibiotics $(100 \mathrm{U} / \mathrm{ml}$ penicillin and $100 \mathrm{U} / \mathrm{ml}$ streptomycin), and maintained at $37^{\circ} \mathrm{C}$ in a humidified air containing $5 \% \mathrm{CO}_{2}$.

\section{Reverse transcription PCR (RT-PCR)}

RT-PCR was performed as described previously (Jeon et al. 2004). The primers were as follows: GLP-1 receptor, forward, 5'-TTTCCTCACGGAAGCGCCACTCC-3'; reverse, 5'-GGATAACGAACAGCAGCGGAACTCCC3', cyclin D1, forward, 5'-GAACTGCTTCTGCTGAA CAAGC-3'; reverse, 5'-CTTCGCGGATGCCACTACT TG-3'. The rat GAPDH gene was used as an internal control.

\section{Western blot analysis}

Western blot analysis was performed as described previously (Kim et al. 2004). The cells were solubilized with RIPA buffer $(25 \mathrm{mM}$ Tris $/ \mathrm{HCl}, \mathrm{pH} 7 \cdot 4,0 \cdot 1 \%$ SDS, $0 \cdot 1 \%$ Triton X-100, $1 \%$ sodium deoxycholate, $150 \mathrm{mM} \mathrm{NaCl}$, $1 \mathrm{mM}$ EDTA, $1 \mathrm{mM} \mathrm{Na} \mathrm{VO}_{4}, 1 \mathrm{mM}$ PMSF, $1 \mu \mathrm{g} / \mathrm{ml}$ aprotinin, and $1 \mu \mathrm{g} / \mathrm{ml}$ leupeptin). Total protein $(30 \mu \mathrm{g})$ was separated by $10 \%$ SDS/PAGE and transferred onto nitrocellulose membrane. The blot was incubated with an appropriate antibody at $4{ }^{\circ} \mathrm{C}$ overnight. After extensive washing, the immunocomplexes were detected using Western Blotting Luminol Reagent. Equal loading of sample was corrected using the band intensity of $\beta$-tubulin (52 kDa).

\section{Plasmids and transient transfection assays}

pCMV-ERK1 was kindly provided by Dr P E Shaw (School of Biomedical Science, University of Nottingham, Nottingham, UK). Human cyclin D1 promoter fragments linked to luciferase vector pGL3 basic reporter were kindly provided by Dr O Tetsu and Dr F McCormick (University of California-San Francisco, San Francisco, CA, USA). pcDNA3-CREB and -KCREB vectors were kindly provided by Dr R H Goodman (Volum Institute, Oregon Health \& Science University, Portland, OR, USA). Transient transfection was performed using Lipofectamine $^{\mathrm{TM}} 2000$ reagent according to the manufacturer's instructions. Briefly, the cells were plated at a density of $4 \times 10^{5}$ cells/well in a six-well plate 3 days before the transfection and then were transfected by mixing plasmid $(1 \mu \mathrm{g})$ and Lipofectamine $(2 \mu \mathrm{l})$ in $1 \mathrm{ml}$ OPTI-MEM. Six hours after transfection, culture media were replaced with fresh culture media. pCMV/ $\beta$-gal $(0 \cdot 1 \mu \mathrm{g})$ was cotransfected into cells to check the transfection efficiency.

\section{Electrophoretic mobility shift assay (EMSA)}

Nuclear extracts were isolated as previously described (Kim et al. 2004). Nuclear extracts $(5 \mu \mathrm{g})$ were incubated 
with the $\left[\gamma_{-}{ }^{32} \mathrm{P}\right] \mathrm{ATP}-\mathrm{labeled}$ CRE oligonucleotide (30 000 c.p.m.) in binding buffer $(10 \mathrm{mM}$ Tris/ $\mathrm{HCl}, \mathrm{pH}$ 7.5, $50 \mathrm{mM} \mathrm{NaCl}, 1 \mathrm{mM} \mathrm{MgCl}_{2}, 0.5 \mathrm{mM}$ EDTA, $0.5 \mathrm{mM}$ DTT, $1 \mu \mathrm{g}$ poly (dI-dC), and $5 \%$ glycerol) for $20 \mathrm{~min}$ at $4{ }^{\circ} \mathrm{C}$. The reaction product was resolved on a $5 \%$ nondenaturing polyacrylamide gel in Tris/borate/ EDTA buffer. The gel was dried and subjected to autoradiography. For immune-supershift assay, nuclear extracts were preincubated with specific antibodies $(5 \mu \mathrm{g})$ against CREB, phospho-CREB, ATF-2, phosphoATF-2, c-Jun, and c-Fos for $30 \mathrm{~min}$ prior to the addition of ${ }^{32} \mathrm{P}$-labeled probe. For competition assay, the samples were preincubated with a 100-fold molar excess of unlabeled CRE and AP-1 oligonucleotides for $30 \mathrm{~min}$ prior to the addition of ${ }^{32} \mathrm{P}$-labeled probe. The oligonucleotides used were as follows: putative CRE oligonucleotide of rat cyclin D1 (5'-CAACAGTAACGTCACTCGGACTAC$\left.3^{\prime}\right)$, CRE consensus oligonucleotide with mutation (underlined; 5'-AGAGATTGCCTGTGGTCAGAGAG CTACC- $3^{\prime}$ ), and AP-1 consensus oligonucleotide (5'CGCTTGATGAGTCAGCCGGAA-3').

\section{Chromatin immunoprecipitation (ChIP) assay}

A ChIP assay was performed as previously described (Gerrish et al. 2001) with minor modifications. An aliquot $(10 \mu \mathrm{l})$ of input and immunoprecipitated DNA was amplified with following temperature profiles: $5 \mathrm{~min}$ at $95{ }^{\circ} \mathrm{C}$; 25 cycles of $30 \mathrm{~s}$ at $95^{\circ} \mathrm{C}, 45 \mathrm{~s}$ at $58{ }^{\circ} \mathrm{C}$, and $30 \mathrm{~s}$ at $72{ }^{\circ} \mathrm{C}$; and $7 \mathrm{~min}$ at $72{ }^{\circ} \mathrm{C}$. The primers used to amplify of the putative CRE site ( $151 \mathrm{bp}$ fragment) of the rat cyclin D1 promoter were as follows: forward, from -169 , 5'-TCACTGCTCCCGAGCCCC-3'; reverse, from -19 , 5'-CTCTGGAGGCTGCAGGAC-3'. As a negative control, a portion of the cyclin D1 open reading frame was amplified.

\section{Statistical analysis}

The relative band densities were quantified using Scion Imaging software (Scion Corporation, Frederick, MD, USA). All data were expressed as means \pm S.D. The data were analyzed using one-way analysis of variance (ANOVA) with Origin 7.0 software (Microcal Software, Northampton, MA, USA). Statistical comparisons among the groups were done using Bonferroni's multiple range $t$-test after the ANOVA. $P<0.05$ was accepted as being statistically significant.

\section{Results}

EX induces cyclin D1 expression in INS-1 cells

EX-induced cyclin D1 protein expression was dosedependent $(0 \cdot 1-10 \mathrm{nM})$ with a maximal effect at $10 \mathrm{nM}$
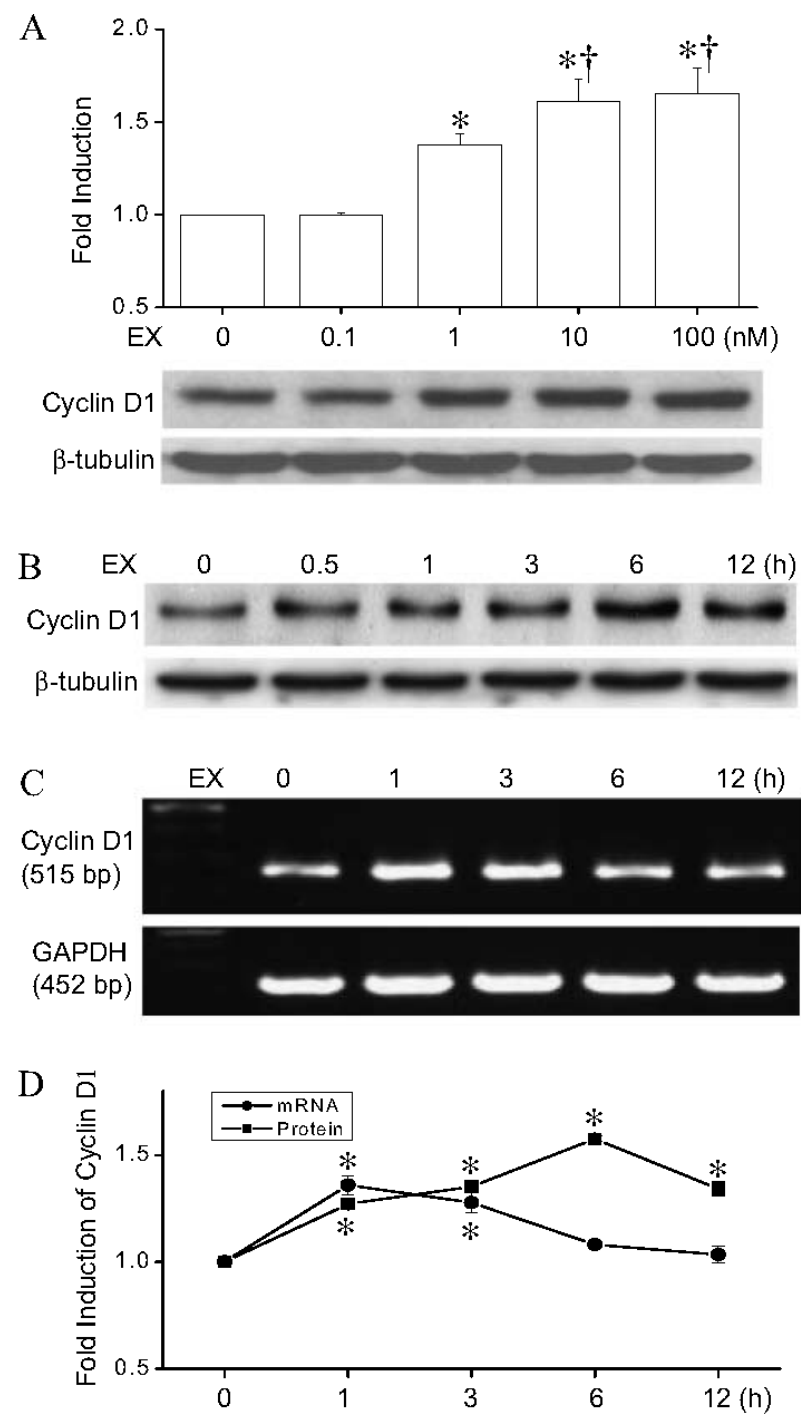

Figure 1 EX induces cyclin D1 expression in INS-1 cells. (A) INS-1 cells were exposed to EX at the indicated concentrations for $6 \mathrm{~h}$ to determine dose-dependent expression of cyclin D1 protein. Data are expressed as the mean ( \pm s.D.) density ratio of cyclin D1 to $\beta$-tubulin from three independent experiments. ${ }^{\star} P<0.05$ versus untreated control value; $\uparrow P<0.05$ versus $1 \mathrm{nM}$. (B) INS- 1 cells were exposed to EX $(10 \mathrm{nM})$ for the indicated times to determine time-dependent expression of cyclin D1 protein. (C) RT-PCR analysis of time-dependent expression of cyclin D1 mRNA. (D) Results of $B$ and $C$ are plotted as the mean ( \pm S.D.) density ratio of cyclin D1 to $\beta$-tubulin protein (B) or to GAPDH mRNA (C) from three independent experiments. ${ }^{*} P<0 \cdot 05$ versus untreated control value.

in INS-1 cells (Fig. 1A). However, no further increase in cyclin D1 protein was observed at a concentration of $100 \mathrm{nM}$. Based on these results, the concentration of EX was set at $10 \mathrm{nM}$ in other experiments. The time course of cyclin D1 induction by EX $(10 \mathrm{nM})$ was investigated. 
Cyclin D1 protein was initially induced at $0.5 \mathrm{~h}$, reaching its peak at $6 \mathrm{~h}$, and then decreased at $12 \mathrm{~h}$ (Fig. $1 \mathrm{~B}$ and D). The RT-PCR result showed that cyclin D1 mRNA expression was significantly increased between 1 and $3 \mathrm{~h}$ after EX and then returned to basal level by $6 \mathrm{~h}$ (Fig. 1C and D).

\section{EX acts through GLP-1 receptor in inducing cyclin D1}

We investigated the mRNA expressions of GLP-1 receptor in rat islets and pancreatic $\beta$-cells. As shown in Fig. 2A, GLP-1 receptor mRNA expression was significantly high in INS-1 and RINm5F cells compared with the islet cells.

To test the possible involvement of GIP receptor in cyclin D1 protein induction by EX, INS-1 cells were pretreated with $10 \mu \mathrm{M}$ GIP-(6-30), a GIP receptor antagonist, for $1 \mathrm{~h}$. Cyclin D1 protein induction by EX was not significantly changed. However, exendin-(9-39) amide, a GLP-1 receptor antagonist, inhibited EX-induced cyclin D1 expression down to the control level (Fig. 2B).

ERK is not involved in EX-induced cyclin D1 expression

Since cyclin D1 induction by mitogens is generally involved in the activation of a class of mitogen-activated protein kinases (MAPKs), specifically ERK1/2, the involvement of ERK in EX-induced cyclin D1 expression was investigated. EX induced the phosphorylation of ERK1/2 and Raf-1, an upstream activator of ERK1/2 (Fig. 3A), but not the phosphorylation of p38 MAPK and c-Jun N-terminal kinase (data not shown). Meanwhile, MAPKs inhibitors PD98059, SB203580, and SP600125 had no effect on EX-induced cyclin D1 expression (Fig. 3B). Moreover, cells transiently transfected with exogenous ERK1 showed no difference in cyclin D1 protein level compared with the empty vector group (Fig. 3C).

\section{cAMP/PKA signaling is involved in EX induction of cyclin} D1 expression

The involvement of cAMP in cyclin D1 expression was evaluated since GLP-1 agonists were reported to activate the cAMP/PKA pathway via the GLP-1 receptor. Forskolin, a cAMP-increasing agent, significantly induced cyclin D1 expression, and the induction by EX or forskolin was completely blocked by the PKA-specific inhibitor H-89 (Fig. 4A). Treatment with dibutyryl cAMP $(100 \mu \mathrm{M})$, a membrane-permeable cAMP analog, significantly induced cyclin D1 protein expression (data not shown). Next we examined the activation of ERK1/2 by intracellular cAMP level. Compared with EX, forskolin induced ERK1/2 phosphorylation for longer duration (compare p-ERK1/2 in Fig. 4B with that
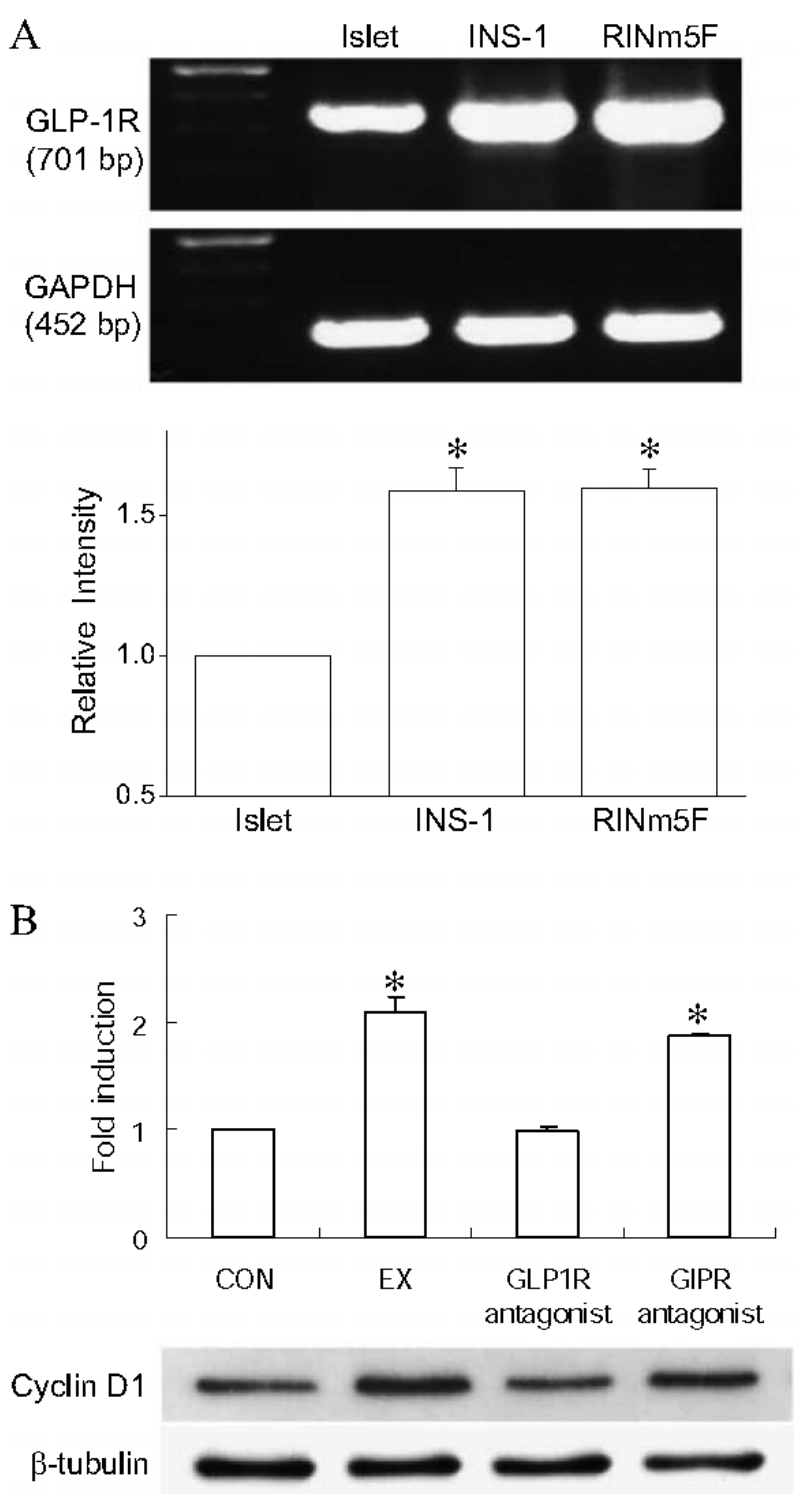

Figure 2 (A) GLP-1 receptor mRNA expression in rat islet, INS-1, and RINm5F cells. The expression levels of GLP-1 receptor (GLP-1R) and GAPDH (internal control) mRNAs were measured by RT-PCR. Data are expressed as the mean ( \pm S.D.) density ratio of GLP-1 receptor to GAPDH from three independent experiments. ${ }^{*} P<0.05$ versus islet cells. (B) INS- 1 cells were pretreated with GLP-1 receptor (GLP1R) antagonist or GIP receptor (GIPR) antagonist (both $10 \mu \mathrm{M}$ ) for $1 \mathrm{~h}$ and treated with EX $(10 \mathrm{nM})$ for $6 \mathrm{~h}$ to examine the specificity of GLP-1 receptor for EX. CON, control. ${ }^{*} P<0.05$ versus untreated control value or GLP-1 receptor antagonist.

in Fig. 3A). Pretreatment with $\mathrm{H}-89$ did not only reduce the EX-induced ERK1/2 phosphorylation to the basal level (Fig. 4C, lane 3), but also decreased its untreated basal level (Fig. 4C, lane 2). 


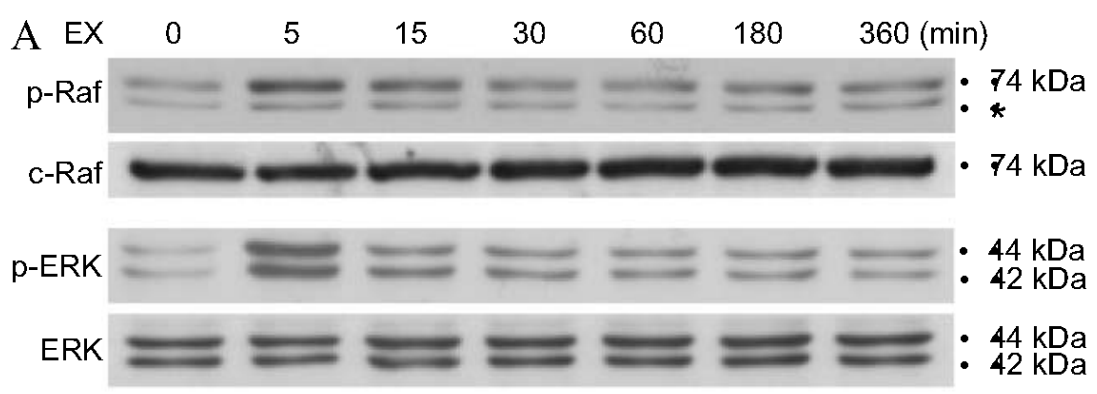

$\mathrm{B}$

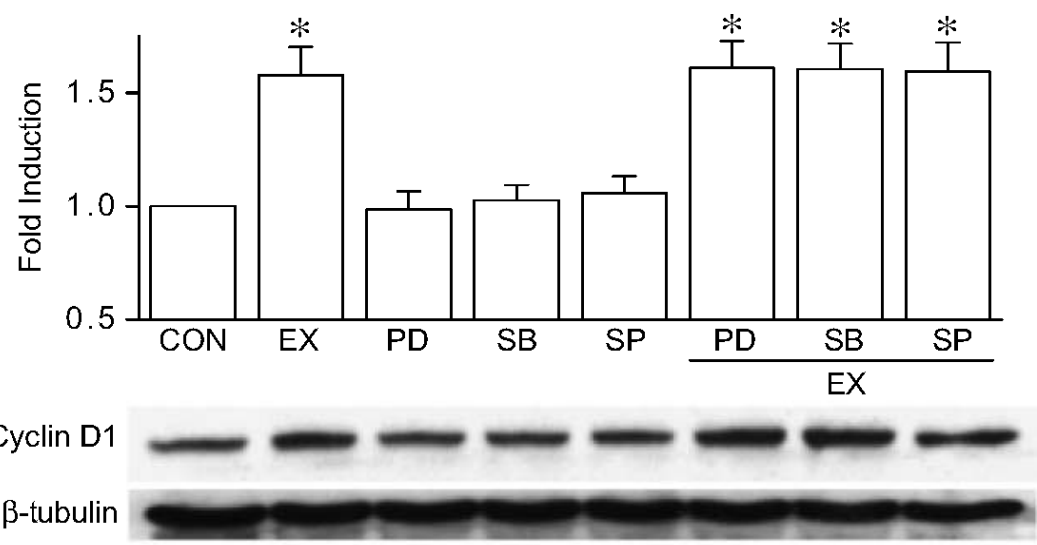

$\mathrm{C}$

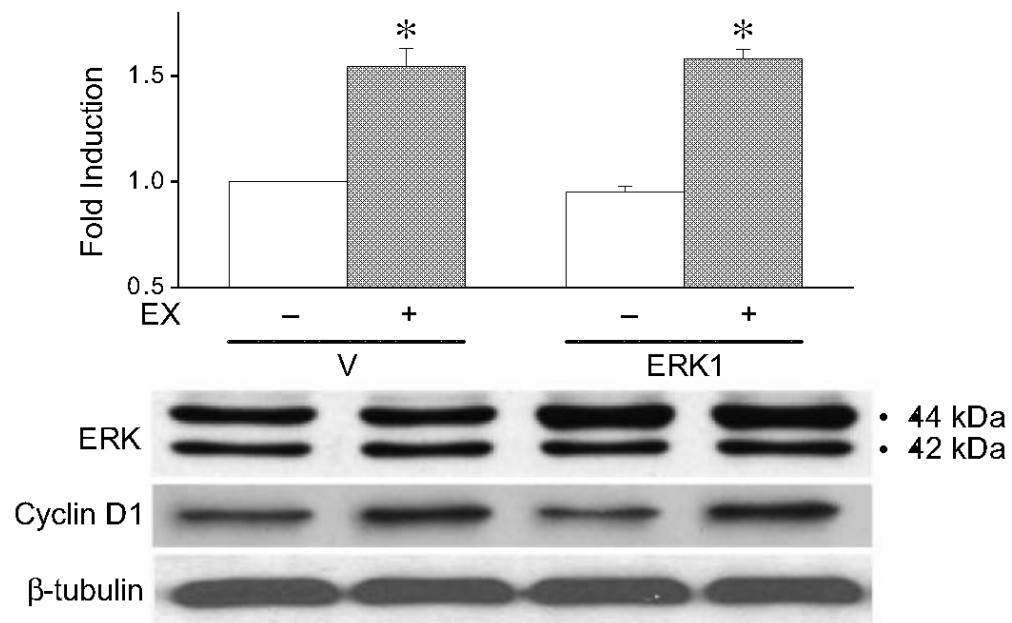

Figure 3 Effect of ERK1/2 on cyclin D1 expression. (A) Following the serum starvation for $24 \mathrm{~h}$, INS-1 cells were exposed to EX $(10 \mathrm{nM})$ for the indicated times. The protein levels of phospho-Raf, phospho-ERK1/2, and their respective total forms were analyzed by Western blot. Each result is representative of three independent experiments. The asterisk shows a non-specific band. (B) Cells were pretreated with PD98059 (PD, $10 \mu \mathrm{M}$ ), SB203580 (SB, $10 \mu \mathrm{M})$, or SP600125 (SP, $10 \mu \mathrm{M})$ for $30 \mathrm{~min}$, and then incubated with EX $(10 \mathrm{nM})$ for an additional $6 \mathrm{~h}$. Cyclin D1 protein levels were measured by Western blot. Each result is representative of three independent experiments. Data are expressed as the mean ( \pm S.D.) density ratio of cyclin D1 to $\beta$-tubulin from three independent experiments. ${ }^{*} P<0.05$ versus control $(\mathrm{CON})$. (C) Cells were transiently transfected with either the empty vector cassette (pcDNA3; V) or pCMV-ERK1 (ERK1). Following serum starvation for $24 \mathrm{~h}$, the cells were incubated with EX $(10 \mathrm{nM})$ for $6 \mathrm{~h}$. The protein levels of cyclin D1 and ERK1/2 were measured by Western blot. Equal loading of protein was verified by reprobing the same blot for $\beta$-tubulin. Data are expressed as the mean ( \pm S.D.) density ratio of cyclin D1 to $\beta$-tubulin from three independent experiments. ${ }^{\star} P<0.05$ versus untreated control value. 
A

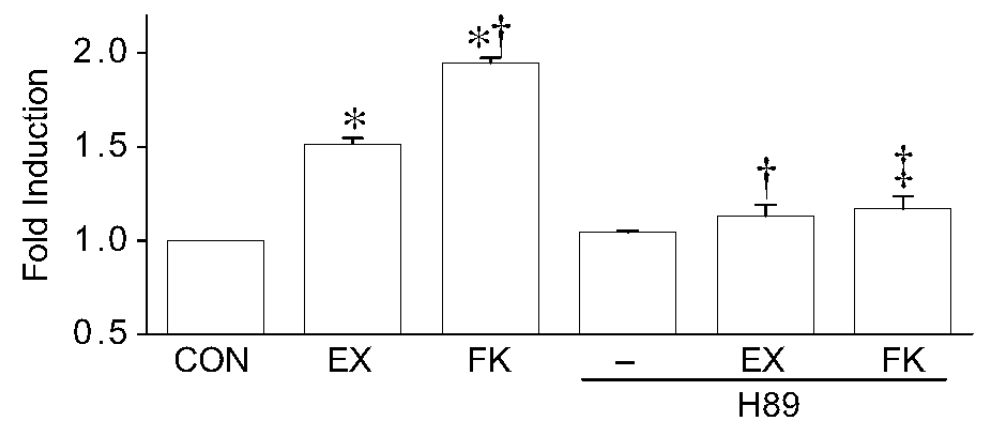

Cyclin D1

$\beta$-tubulin
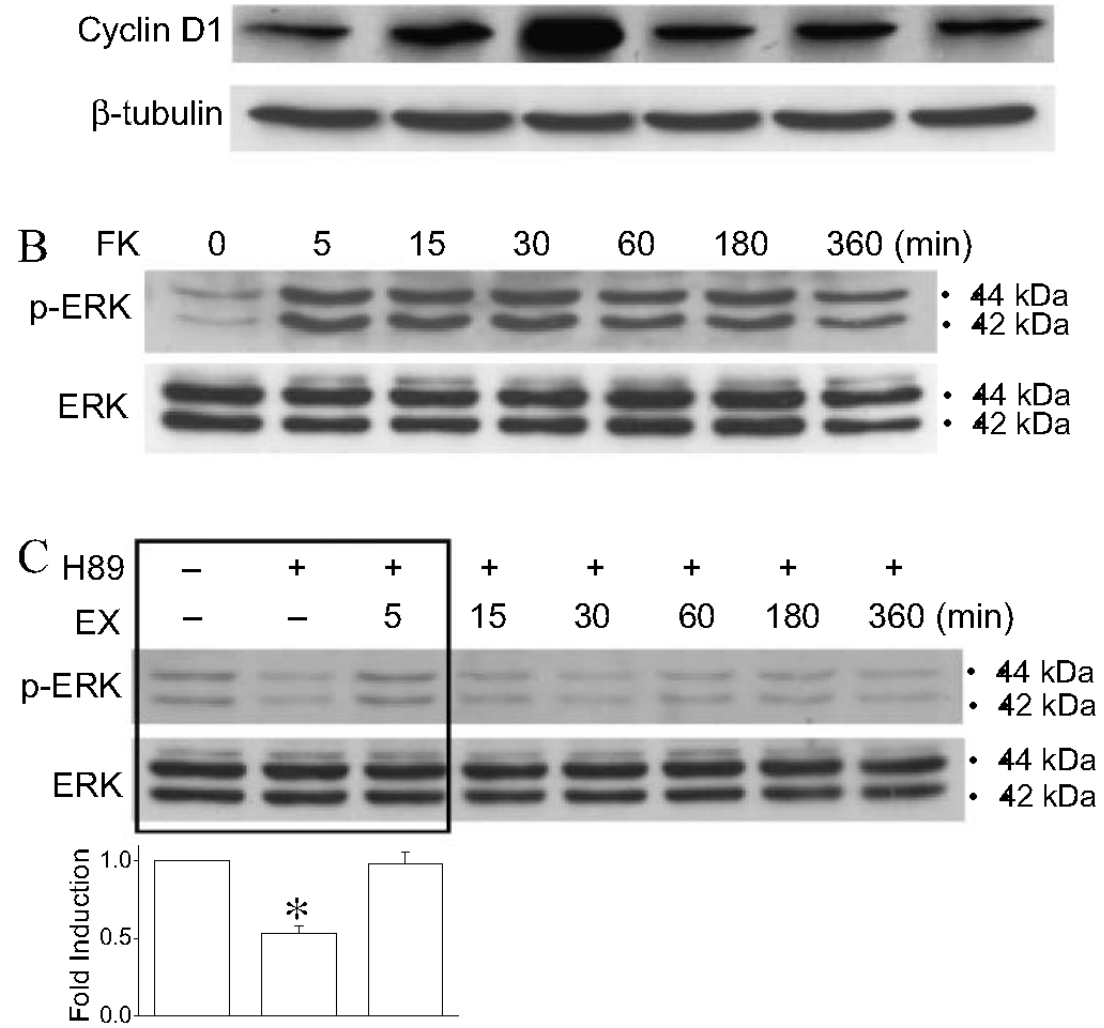

Figure 4 Effects of forskolin and $\mathrm{H}-89$ on cyclin D1 protein expression in INS-1 cells. (A) Following serum starvation for $24 \mathrm{~h}$, INS-1 cells were pretreated with $\mathrm{H}-89(5 \mu \mathrm{M})$ for $30 \mathrm{~min}$, and the incubated with EX $(10 \mathrm{nM})$ or forskolin (FK; $5 \mu \mathrm{M})$ for an additional $6 \mathrm{~h}$. The protein level of cyclin D1 was measured by Western blot. Data are expressed as the mean ( \pm s.D.) density ratio of cyclin D1 to $\beta$-tubulin from three independent experiments. ${ }^{*} P<0.05$ versus control $(\mathrm{CON}) ;+P<0.05$ versus EX; $\neq P<0.05$ versus FK. (B) The cells were treated with FK for the indicated times and protein levels of ERK1/2 measured by Western blot. Each result is representative of three independent experiments. (C) The cells were pretreated with $\mathrm{H}-89$ for $30 \mathrm{~min}$ and then incubated with EX for the indicated times. The protein levels of ERK $1 / 2$ and their phosphorylation status were measured by Western blot. Pretreatment of $\mathrm{H}-89$ completely blocked EX-induced ERK1/2 phosphorylation down to the basal level. The graph inside the box represents the mean ( \pm S.D.) density ratios of phospho-ERK to ERK from three independent experiments. ${ }^{*} P<0.05$ versus no treatment.

The CRE site is required for activation of cyclin D1 promoter by EX

The involvement of the putative CRE site located between -48 and -41 in cyclin D1 promoter activation was assessed using promoter fragments (Fig. 5A). As shown in Fig. 5B, EX increased the luciferase activity of pCD $1-96$ by $1 \cdot 7$-fold compared with the control $(P<0 \cdot 05)$, whereas pCD1-29 devoid of the putative CRE site was unresponsive to EX treatment. The significance 

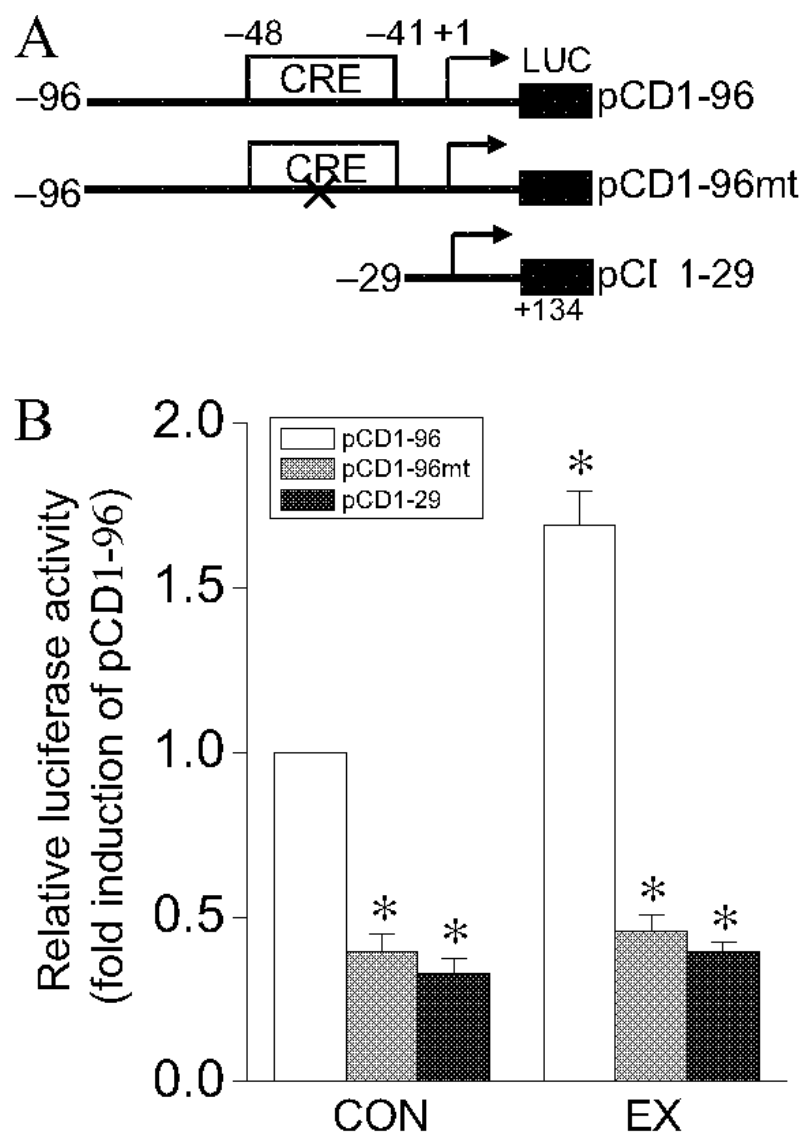

Figure 5 Involvement of CRE site in EX-induced cyclin D1 transcription. (A) Schematic representation of the cyclin D1 promoter deletion constructs. The cross shows the mutation in the CRE site. (B) INS-1 cells were transiently cotransfected with cyclin $\mathrm{D} 1$ promoters $(1 \mu \mathrm{g})$ and $\mathrm{pCMV} / \beta$-gal $(0 \cdot 1 \mu \mathrm{g}$, as an internal control). Following serum starvation for $24 \mathrm{~h}$, the cells were incubated with EX for $10 \mathrm{~h}$. Cells were then solubilized in lysis buffer and luciferase and $\beta$-galactosidase activities were measured. Data are expressed as means \pm S.D. and each value is the fold increase over the corresponding control (CON) value of pCD1-96 from three independent experiments. ${ }^{\star} P<0.05$ versus control of $\mathrm{pCD} 1-96$.

of the CRE site in EX-induced cyclin D1 promoter activity was confirmed by site-directed mutagenesis (Fig. 5B). The mutant CRE construct (pCD1-96 mt) showed a significantly lower luciferase activity in any state compared with pCD1-96.

Transcription factor CREB interacts with the CRE site for the transcriptional activation of cyclin D1 by EX

We first determined the time-dependent phosphorylation of CREB using a specific anti-phospho-CREB antibody, which detects the phosphorylated CREB at serine 133. EX induced a rapid and transient increase in CREB phosphorylation between 5 and 15 min after treatment (Fig. 6A).
Binding activity of nuclear extract to the CRE site within the cyclin D1 promoter was assessed by EMSAs. Although multiple nuclear proteins $(\mathrm{C} 1-\mathrm{C} 4)$ formed complexes with the probe, the band intensity of $\mathrm{C} 2$ was increased between 5 and 15 min by EX treatment (Fig. $6 \mathrm{~B})$. This induction was well correlated with the kinetics of CREB phosphorylation shown in Fig. 6A. The majority of DNA-protein complexes were sequencespecific because a 100-fold molar excess of unlabeled CRE probe completely abolished the binding activity (Fig. 6B, lane 1).

The proteins present in the DNA-protein complexes were characterized using specific antibodies against transcription factors binding to the CRE motif (Fig. 6C). The addition of anti-CREB or anti-phospho-CREB resulted in complete reduction of the $\mathrm{C} 2$ band and moderate reduction of the $\mathrm{C} 3$ and $\mathrm{C} 4$ bands, and a more slowly migrating band was detected (arrowheads in lanes 2 and 3 of Fig. 6C). In contrast, preincubation with antibodies against ATF-2, phospho-ATF-2, c-Jun, or c-Fos did not affect the mobility and intensity of each DNA-protein complex.

In competition assay (Fig. 6D), excess wild-type unlabeled CRE oligonucleotide entirely competed away the multiple complexes but not excess mutant consensus CRE or consensus AP-1 oligonucleotides, suggesting the sequence specificity of the CRE site of cyclin D1 promoter.

To evaluate the functional interaction between CREB protein and CRE site, the cyclin D1 promoter construct (pCD1-96) harboring the CRE site was cotransfected with plasmids expressing constitutively active or dominant-negative forms of CREB into INS-1 cells. Constitutively active CREB consists of the transactivation domain of the viral VP16 protein linked to the CREB DNA-binding domain. KCREB, a protein which binds to endogenous CREB and inhibits its binding to the CRE site within the gene promoter, was used as a dominant-negative CREB. As shown in Fig. 6E, constitutively active CREB remarkably increased both basal and EX-induced promoter activities of pCD1-96, while KCREB completely abolished these responses.

Finally, to further examine whether the increase in transactivation of cyclin D1 gene observed in transfection assay using constitutively active CREB was due to enhanced binding activity of phospho-CREB to the CRE site of the cyclin D1 promoter in vivo, a ChIP assay was performed. As shown in Fig. 7, EX-induced binding activity of the phospho-CREB to CRE site was significantly increased by about $1 \cdot 7$-fold compared with the control.

\section{Discussion}

The present study demonstrates the stimulatory effect of EX on cyclin D1 expression in pancreatic $\beta$-cells. 
Firstly, to verify the expression of GLP-1 receptor on the $\beta$-cells, mRNA levels of the GLP-1 receptor were measured. GLP-1 receptor mRNA was highly expressed in the INS-1 cells and RINm5F cells compared with pancreatic islets (Fig. 2A). Furthermore, exendin-(9-39)
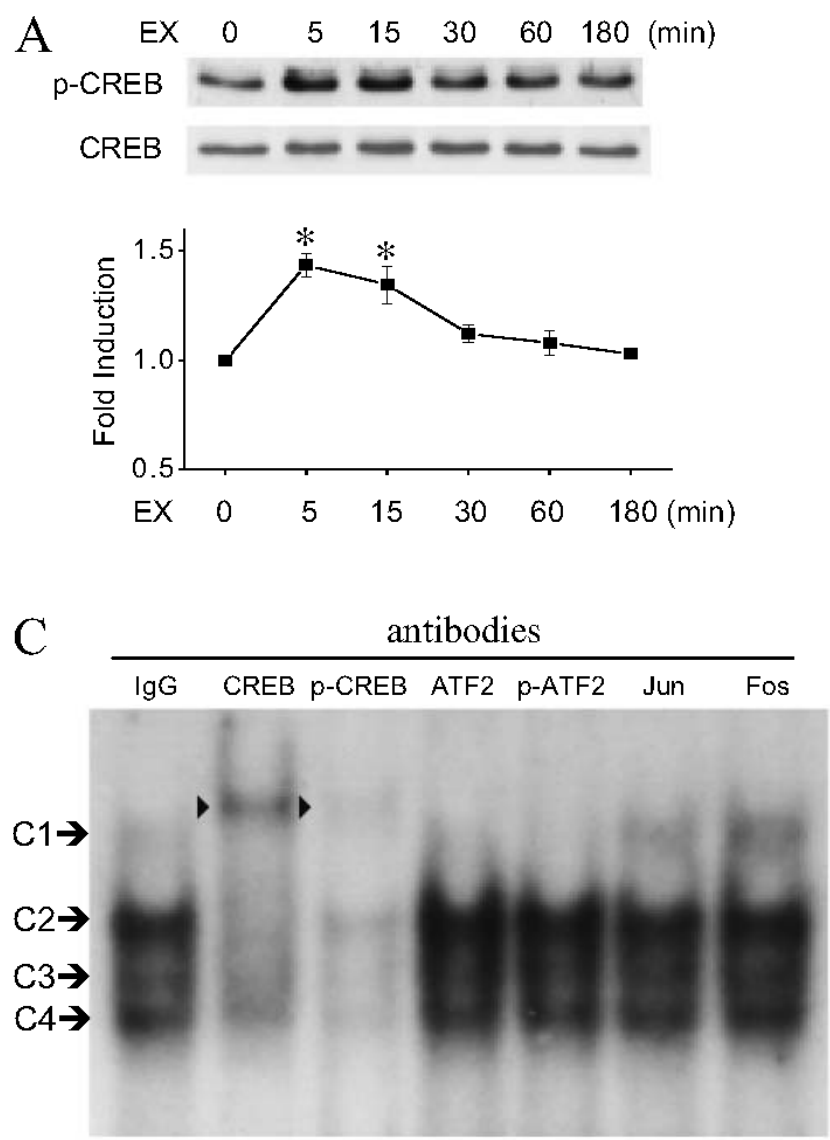

E

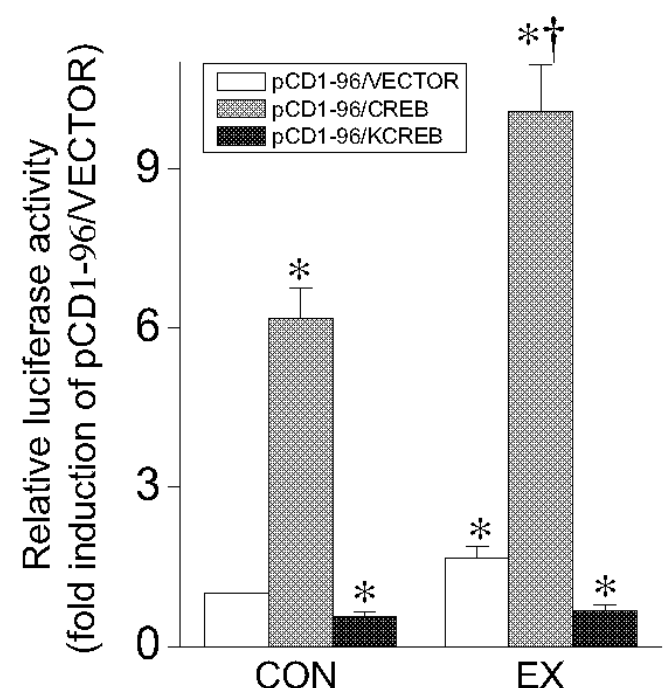

amide, a GLP-1 receptor antagonist, inhibited EXinduced cyclin D1 expression significantly, while GIP-(630), a GIP receptor antagonist, failed to inhibit. This finding is consistent with other studies that binding sites of GLP-1 and GIP were highly ligand-specific in RINm5F

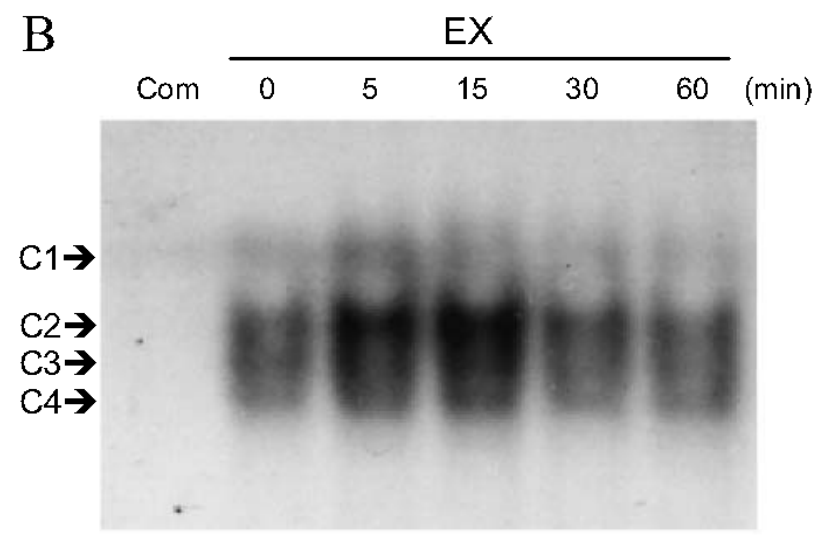

D

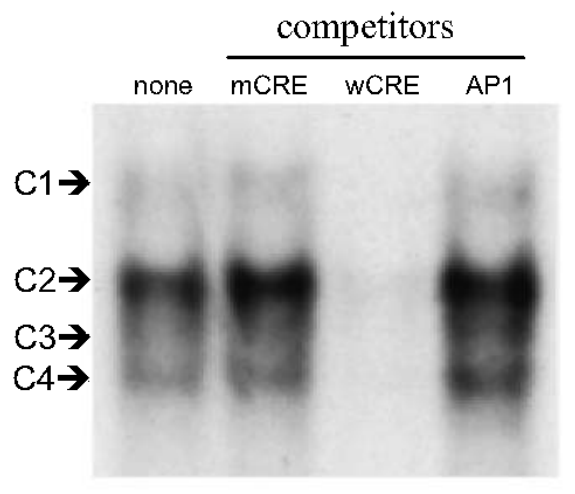



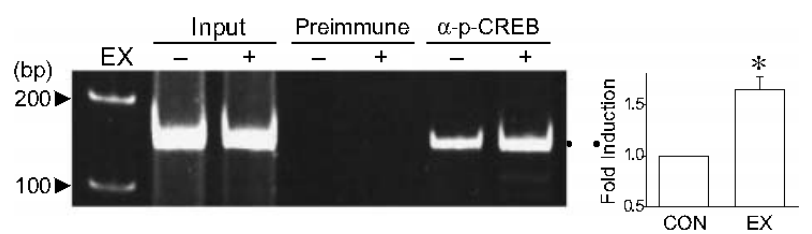

Figure 7 Enhanced binding activity of phospho-CREB to the putative CRE site of the rat cyclin D1 promoter in vivo. The cells were treated with EX $(10 \mathrm{nM})$ for 10 min and the crosslinking was then induced by formaldehyde. Following fragmentation by sonication, the chromatin was immunoprecipitated with preimmune rabbit serum (negative control) and antibody against phospho-CREB ( $\alpha$-p-CREB). PCR amplification of a $151 \mathrm{bp}$ fragment containing the CRE site was performed using the 'input' fraction (positive control) and immunoprecipitated fractions as a template. Data are expressed as the mean ( \pm S.D.) density ratio of $\alpha$-p-CREB to the input fraction from three independent experiments. CON, not treated with EX. ${ }^{*} P<0.05$ versus control.

cells (Gallwitz et al. 1993) and exendin-(9-39) amide inhibited GLP-1-stimulated cAMP production, whereas $\left(\mathrm{Pro}^{3}\right)$ GIP, another GIP antagonist, had no effect (Gault et al. 2003), suggesting that EX induction of cyclin D1 is mediated via the GLP-1 receptor.

The increase in cyclin D1 protein allows its binding to serine/threonine cyclin-dependent kinases (cdk4 or cdk6; Matsushime et al. 1992). The cyclin D1-cdk complexes induce transcriptional activation of S-phase-specific genes leading to the cell proliferation (Sherr 1994). Therefore, the induction of cyclin D1 expression by EX in our study appears to contribute to pancreatic $\beta$-cell proliferation and islet mass increase. This possibility is supported by recent studies that the overexpression of either cyclin D1 alone or in combination with cdk 4 induced $\beta$-cell proliferation in rat and human pancreatic islets (Cozar-Castellano et al. 2004 ) and that cyclin D1 was essential for normal postnatal pancreatic $\beta$-cell growth (Kushner et al. 2005).

Cyclin D1 induction by mitogens is highly dependent on the activation of a class of MAPKs, specifically ERK1/2 (Brunet et al. 1999, Chang \& Karin 2001). In our study, however, MAPK inhibitors including PD98059 had no effect on cyclin D1 expression. Consistent with our finding, others demonstrated that inhibition of ERK1/2 activity using PD98059 did not suppress GLP-1-induced DNA synthesis in INS (832/13) cells (Buteau et al. 2001), suggesting no relevance of ERK1/2 to GLP-1/EX-induced pancreatic $\beta$-cell proliferation. Moreover, the overexpression of exogenous ERK1 did not affect the cyclin D1 expression. Though not tested, ERK2 may also have no action on cyclin D1 expression since EX induced phosphorylation of both ERK1 and ERK2 in a similar pattern (Fig. 3A).

GLP-1-mediated mitogenic signaling has been cAMPdependent in pancreatic $\beta$-cells (Frödin et al. 1995, List \& Habener 2004). In addition, GLP-1 activates immediate early genes such as c-fos, c-Jun, zif268, and jun D, which are involved in cell proliferation, in cAMP/PKAdependent manner (Susini et al. 1998). In the present study, H-89 significantly blocked EX-induced cyclin D1 expression. Therefore, the signaling pathway for EXinduced cyclin D1 expression appears to be through the cAMP/PKA/CREB pathway rather than Raf/ERK1/2, although there is crosstalk between intracellular signaling systems.

Both EX and GLP-1 induce the increase in intracellular cAMP to modulate diverse cellular events (Egan et al. 2003). Most of cAMP-inducible genes including cyclin D1 gene contain one or a few CRE sites (Lalli \& Sassone-Corsi 1994), and the CRE site plays a key role in the regulation of many cellular activities in various cells (D'Amico et al. 2000, Nagata et al. 2001, Moriuchi et al. 2003). Our promoter analyses clearly demonstrated that the putative CRE site was required for the transcriptional regulation of the cyclin D1 in both unstimulated and EX-stimulated states. Moreover, site-directed mutation of the CRE site exhibited a complete loss of EX responsiveness, confirming the involvement and significance of this site in EX-mediated transcriptional activation of the cyclin D1 gene.

CREB has been shown to be responsible for promotion of islet $\beta$-cell survival and proliferation (Drucker 2003, Jhala et al. 2003). Mice expressing a dominant-negative CREB protein in islet $\beta$-cells exhibited a marked reduction in $\beta$-cell mass and a significant increase in $\beta$-cell apoptosis (Jhala et al. 2003). Thus, CREB is likely to

Figure 6 CREB interacts with the putative CRE site of cyclin D1 promoter. (A) Following serum starvation for 24 h, INS-1 cells were treated with EX $(10 \mathrm{nM})$ for indicated times. Then phospho-CREB proteins were measured by Western blot. Data are expressed as the mean ( \pm s.D.) density ratio of phospho-CREB to CREB from three independent experiments. ${ }^{*} P<0 \cdot 05$ versus untreated control value. (B) Time-dependent binding activity of the CRE site within the cyclin D1 promoter. The cells were treated with EX for the indicated times. Then the binding activity of nuclear extracts was analyzed on EMSA with cyclin D1 putative CRE oligonucleotide (5'-CAACAGTAACGTCA CTCGGACTAC-3'). The arrows indicate the position of major DNA-protein complexes (C1-C4). Com, addition of unlabeled CRE probe. (C) For immune-supershift assay, cells were treated with EX for 5 min. Then, specific antibodies against CREB (lane 2), phospho-CREB (lane 3), ATF-2 (lane 4), phospho-ATF-2 (lane 5), c-Jun (lane 6), and c-Fos (lane 7) were preincubated with nuclear extracts for 30 min before the addition of labeled probes. Arrowheads, supershifted band. Lane 1, preimmune IgG. (D) Competition assay was carried out with a 100-fold molar excess of either mutant consensus CRE (mCRE; lane 2), putative CRE (wCRE; lane 3), or consensus AP-1 (AP1; lane 4) oligonucleotides. Lane 1, without oligonucleotide. (E) Cells were transiently cotransfected with pCD1-96 (0.5 $\mu \mathrm{g})$ and $0 \cdot 5 \mu \mathrm{g}$ of CREB or KCREB and $\mathrm{pCMV} / \beta$-gal $(0 \cdot 1 \mu \mathrm{g})$. Following serum starvation for $24 \mathrm{~h}$, the cells were incubated with EX for $10 \mathrm{~h}$. Cells were then solubilized and luciferase and $\beta$-galactosidase activities were measured. Data are expressed as means \pm s.D. and each value is the fold increase over the control $(\mathrm{CON})$ value of $\mathrm{pCD} 1-96 / \mathrm{VECTOR}$ from three independent experiments. * $P<0 \cdot 05$ versus control of pCD1-96/VECTOR; $\uparrow P<0 \cdot 05$ versus control of $p C D 1-96 / C R E B$. 
contribute to $\beta$-cell growth and survival. Our results showed the rapid induction of CREB phosphorylation along with its increased DNA-binding activity by EX. Such a rapid EX-induced CREB activation was also reported in another pancreatic $\beta$-cell line, MIN6 (Jhala et al. 2003). Though CREB can bind to CRE site even in the unphosphorylated state, the stimulatory effect of phosphorylated CREB on transcriptional activation is more potent (Rosenberg et al. 2002). Several transcription factors including CREB were known to bind to the putative CRE site of the cyclin D1 promoter, leading to the transcriptional activation of cyclin D1 gene. For instance, c-Fos and c-Jun bound to the CRE site in serum-induced fibroblasts (Brown et al. 1998), whereas estrogen induced the binding of a ATF/c-Jun heterodimer in MCF-7 cells (Sabbah et al. 1999). In our immunesupershift assay, the supershifted band was detectable on the addition of antibody against CREB or phosphoCREB, but not with antibody against ATF-2 or AP-1. In addition, the functional role of CREB in stimulating the cyclin D1 gene promoter by EX was confirmed using plasmids expressing constitutively active CREB and dominant-negative KCREB. Lastly, our ChIP assay clearly demonstrated that EX enhanced the binding activity of phospho-CREB to the putative CRE site over the basal control under in vivo conditions. Therefore, EX-mediated cAMP/CREB signaling increases the level of CREB phosphorylation and subsequently its binding activity to the putative CRE site for the transcriptional activation of cyclin D1 gene.

Collectively, EX increases cyclin D1 expression via a cAMP/PKA signaling-mediated activation of the putative CRE site within cyclin D1 promoter, and the interaction of phospho-CREB with the putative CRE site is implicated in both basal and EX-induced cyclin D1 transcription in the pancreatic $\beta$-cell line INS-1.

\section{Acknowledgements}

We are grateful to Dr Hongtae Kim (Division of Radiation Oncology, Mayo Clininc, Rochester, MN, USA) and Dr Yong-Moon Park (Department of Preventive Medicine, College of Medicine, The Catholic University of Korea, Soeul, Korea) for technical advice and statistical analysis, respectively.

\section{Funding}

This research was grant-supported by Korea Science and Engineering Foundation (R-2004-000-10127-0), Republic of Korea. The authors declare that there is no conflict of interest that would prejudice the impartiality of this scientific work.

\section{References}

Brown JR, Nigh E, Lee RJ, Ye H, Thompson MA, Saudou F, Pestell RG \& Greenberg ME 1998 Fos family members induce cell cycle entry by activating cyclin D1. Molecular and Cellular Biology 18 5609-5619.

Brunet A, Roux D, Lenormand P, Dowd S, Keyse S \& Pouysségur J 1999 Nuclear translocation of p42/p44 mitogen-activated protein kinase is required for growth factor-induced gene expression and cell cycle entry. EMBO Journal 18 664-674.

Buteau J, Foisy S, Rhodes CJ, Carpenter L \& Biden TJ 2001 Protein kinase $\mathrm{C} \zeta$ activation mediates glucagon-like peptide-1-induced pancreatic $\beta$-cell proliferation. Diabetes $502237-2243$.

Chang L \& Karin M 2001 Mammalian MAP kinase signaling cascades. Nature 410 37-40

Cozar-Castellano I, Takane KK, Bottino R, Balamurugan AN \& Stewart AF 2004 Induction of $\beta$-cell proliferation and retinoblastoma protein phosphorylation in rat and human islets using adenovirus-mediated transfer of cyclin-dependent kinase-4 and cyclin $\mathrm{D}_{1}$. Diabetes 53 149-159.

D'Amico M, Hulit J, Amanatullah DF, Zafonte BT, Albanese C, Boouzahzah B, Fu M, Augenlicht LH, Donehower LA, Takemaru K et al. 2000 The integrin-linked kinase regulates the cyclin D1 gene through glycogen synthase kinase $3 \beta$ and cAMP-responsive element binding protein-dependent pathways. Journal of Biological Chemistry 275 32649-32657.

De León DD, Deng S, Madani R, Ahima RS \& Drucker DJ 2003 Role of endogenous glucagon-like peptide-1 in islet regeneration after partial pancreatectomy. Diabetes 52 365-371.

Drucker DJ 2003 Glucagon-like peptide-1 and the islet $\beta$-cell: augmentation of cell proliferation and inhibition of apoptosis. Endocrinology 144 5145-5148.

Drucker DJ, Philippe J, Mojsov S, Chick WL \& Habener JF 1987 Glucagon-like peptide-1 stimulates insulin gene expression and increases cyclic AMP levels in a rat islet cell line. PNAS $843434-3438$.

Egan JM, Bulotta A, Hui H \& Perfetti R 2003 GLP-1 receptor agonists are growth and differentiation factors for pancreatic islet beta cells. Diabetes/Metabolism Research and Reviews 19 115-123.

Frödin M, Sekine N, Roche E, Filloux G, Prentki M, Wollheim C \& Van Obberghen E 1995 Glucose, other secretagogues, and nerve growth factor stimulate mitogen-activated protein kinase in the insulin-secreting $\beta$-cell line, INS-1. Journal of Biological Chemistry $2707882-7889$.

Gallwitz B, Witt M, Folsch UR, Creutzfeldt W \& Schmidt WE 1993 Binding specificity and signal transduction of receptors for glucagons-like peptide-1 (7-36) amide and gastric inhibitory polypeptide on RINm5F insulinoma cells. Journal of Molecular Endocrinology 10 259-268.

Gault VA, O'Harte FPM, Harriott P, Mooney MH, Green BD \& Flatt PR 2003 Effects of the novel $\left(\operatorname{Pro}^{3}\right)$ GIP antagonist and exendin(9-39)amide on GIP- and GLP-1-induced cyclic AMP generation, insulin secretion and postprandial insulin release in obese diabetic (ob/ob) mice: evidence that GIP is the major physiological incretin. Diabetologia 46 222-230.

Gerrish K, Cissell MA \& Stein R 2001 The role of hepatic nuclear factor $1 \alpha$ and PDX-1 in transcriptional regulation of the $p d x-1$ gene. Journal of Biological Chemistry 276 47775-47784.

Jeon SY, Baek K-H, Kim Y-S, Park C-G, Kwon HS, Ko SH, Song K-H, Yoo SJ, Son HS, Lee KW et al. 2004 Differentially up-regulated genes in proliferating porcine neonatal pancreas cells caused by epidermal growth factor. Journal of Cellular Biochemistry 91 354-364.

Jhala US, Canettieri G, Screaton RA, Kulkarni RN, Krajewski S, Reed J, Walker J, Lin X, White M \& Montminy M 2003 cAMP promotes pancreatic $\beta$-cell survival via CREB-mediated induction of IRS2. Genes \& Development 17 1575-1580. 
Kim M-J, Ryu GR, Chung J-S, Sim SS, Min DS, Rhie D-J, Yoon SH, Hahn SJ, Kim M-S \& Jo Y-H 2003 Protective effects of epicatechin against the toxic effects of streptozotocin on rat pancreatic islets: in vivo and in vitro. Pancreas 26 292-299.

Kim M-J, Ryu GR, Kang J-H, Sim SS, Min DS, Rhie D-J, Yoon SH, Hahn SJ, Jeong I-K, Hong K-J et al. 2004 Inhibitory effects of epicatechin on interleukin-1-induced inducible nitric oxide synthase expression in RINm5F cells and rat pancreatic islets by down-regulation of NF-B activation. Biochemical Pharmacology 68 1775-1785.

Kushner JA, Ciemerych MA, Sicinska E, Wartschow LM, Teta M, Long SY, Sicinski P \& White MF 2005 Cyclins D2 and D1 are essential for postnatal pancreatic $\beta$-cell growth. Molecular and Cellular Biology 25 3752-3762.

Lalli E \& Sassone-Corsi P 1994 Signal transduction and gene regulation. Journal of Biological Chemistry 269 17359-17362.

Leech CA, Castonguay MA \& Habener JF 1999 Expression of adenylyl cyclase subtypes in pancreatic $\beta$-cells. Biochemical and Biophysical Research Communications 254 703-706.

List JF \& Habener JF 2004 Glucagon-like peptide 1 agonists and the development and growth of pancreatic $\beta$-cells. American Journal of Physiology Endocrinology and Metabolism 286 E875-E881.

Matsushime H, Ewen ME, Strom DK, Kato JY, Hanks SK, Roussel MF \& Sherr CJ 1992 Identification and properties of an atypical catalytic subunit (p34 PSK-J3/Cdk4) for mammalian D type G1 cyclins. Cell $71323-334$.

Montminy M 1997 Transcriptional regulation by cyclic AMP. Annual Review of Biochemistry 66 807-822.

Moriuchi A, Ido A, Nagata Y, Nagata K, Uto H, Hasuike S, Hori T, Hirono S, Hayashi K \& Tsubouchi H 2003 A CRE and the region occupied by a protein induced by growth factors contribute to up-regulation of cyclin D1 expression in hepatocytes. Biochemical and Biophysical Research Communications 300 415-421.

Nagata D, Suzuki E, Nishimatsu H, Satonaka H, Goto A, Omata M \& Hirata Y 2001 Transcriptional activation of the cyclin D1 gene is mediated by multiple cis-elements, including SP1 sites and a cAMP-responsive element in vascular endothelial cells. Journal of Biological Chemistry 276 662-669.

Ørskov C 1992 Glucagon-like peptide-1, a new hormone of the entero-insular axis. Diabetologia 35 701-711.

Perfetti R \& Merkel P 2000 Glucagon-like peptide-1: a major regulator of pancreatic $\beta$-cell function. European Journal of Endocrinology 143 717-725.
Perry T \& Greig NH 2003 The glucagon-like peptides: a doubleedged therapeutic sword? Trends in Pharmacological Sciences 24 377-383.

Rosenberg D, Groussin L, Jullian E, Perlemoine K, Bertagna X \& Bertherat J 2002 Role of the PKA-regulated transcription factor CREB in development and tumorigenesis of endocrine tissues. Annals of the New York Academy of Sciences 968 65-74.

Sabbah M, Courilleau D, Mester J \& Redeuilh G 1999 Estrogen induction of the cyclin D1 promoter: involvement of a cAMP response-like element. PNAS 96 11217-11222.

Sherr CJ 1994 G1 phase progression: cycling on cue. Cell $79551-555$.

Susini S, Roche E, Prentki M \& Schlegel W 1998 Glucose and glucoincretin peptides synergize to induce c-fos, c-jun, zif268, and nur-77 gene expression in pancreatic $\beta$ (INS-1) cells. FASEB Journal $121173-1182$.

Tourrel C, Bailbé D, Meile M-J, Kergoat M \& Portha B 2001 Glucagon-like peptide- 1 and exendin- 4 stimulate $\beta$-cell neogenesis in streptozotocin-treated newborn rats resulting in persistently improved glucose homeostasis at adult age. Diabetes 50 1562-1570.

Tourrel C, Bailbé D, Lacorne M, Meile M-J, Kergoat M \& Portha B 2002 Persistent improvement of type 2 diabetes in the Goto-Kakizaki rat model by expansion of the $\beta$-cell mass during the prediabetic period with glucagons-like peptide-1 or exendin-4. Diabetes 51 1443-1552.

Xu G, Stoffers DA, Habener JF \& Bonner-Weir S 1999 Exendin-4 stimulates both $\beta$-cell replication and neogenesis, resulting in increased $\beta$-cell mass and improved glucose tolerance in diabetic rats. Diabetes 48 2270-2276.

Yan Y-X, Nakagawa H, Lee M-H \& Rustgi AK 1997 Transforming growth factor- $\alpha$ enhances cyclin D1 transcription through the binding of early growth response protein to a cis-regulatory element in the cyclin D1 promoter. Journal of Biological Chemistry $27233181-33190$.

Received in final form 17 November 2005

Accepted 22 December 2005

Made available online as an Accepted Preprint

22 December 2005 